\title{
Emissions of nitrous oxide, nitrogen oxides and ammonia from a maize field in the North China Plain
}

\author{
Yuanyuan Zhang ${ }^{a}$, Junfeng Liu ${ }^{a}$, Yujing Mu ${ }^{\mathrm{a}, *}$, Shuwei Pei ${ }^{\mathrm{b}}$, Xiaoxiu Lun ${ }^{\mathrm{b}}$, Fahe Chai $^{\mathrm{c}}$ \\ ${ }^{a}$ Research Center for Eco-Environmental Sciences, Chinese Academy of Sciences, Beijing 100085, China \\ ${ }^{\mathrm{b}}$ College of Environmental Science and Engineering, Beijing Forestry University, Beijing 100083, China \\ ${ }^{\mathrm{C}}$ Chinese Research Academy of Environmental Sciences, Beijing 100012, China
}

\section{A R T I C L E I N F O}

\section{Article history:}

Received 15 July 2010

Received in revised form

29 October 2010

Accepted 29 October 2010

\section{Keywords:}

Nitrous oxide

Nitrogen oxides

Ammonia

Fertilizers

Wheat straw

\begin{abstract}
A B S T R A C T
The exchange fluxes of nitrous oxide $\left(\mathrm{N}_{2} \mathrm{O}\right)$, nitrogen oxides $\left(\mathrm{NO}_{\mathrm{x}}\right)$ and ammonia $\left(\mathrm{NH}_{3}\right)$ from a maize field with three different treatments were simultaneously measured using static and dynamic chambers in the North China Plain (NCP) from June 28 to October 11, 2009. The three treatments included control plot (CK, without crop, fertilization and irrigation), fertilizer $\mathrm{N}$ plot (NP) and wheat straw returning plus fertilizer $\mathrm{N}$ plot (SN). $\mathrm{N}$-fertilizer application greatly stimulated the emissions of $\mathrm{N}_{2} \mathrm{O}, \mathrm{NO}_{\mathrm{x}}$ and $\mathrm{NH}_{3}$, with durations of about 10 days for $\mathrm{N}_{2} \mathrm{O}$ and $\mathrm{NO}$, and about 7 days for $\mathrm{NH}_{3}$. Fertilizer loss rates were $1.08 \%$ (NP plot) and $1.20 \%$ (SN plot) as $\mathrm{N}_{2} \mathrm{O}-\mathrm{N}$, were $1.93 \%$ (NP plot) and $0.76 \%$ (SN plot) as NO-N, and were $5.24 \%$ (NP plot) and 3.03\% (SN plot) as $\mathrm{NH}_{3}-\mathrm{N}$. In comparison with the NP plot, the significant low fertilizer loss rates as $\mathrm{NO}-\mathrm{N}$ and $\mathrm{NH}_{3}-\mathrm{N}$ from the SN plot indicated that the wheat straw returning to the field could reduce $\mathrm{NO}_{\mathrm{x}}$ and $\mathrm{NH}_{3}$ emissions. The molar ratio of $\mathrm{NO} / \mathrm{N}_{2} \mathrm{O}$ was greater than unity for most data during the pulse emission periods induced by fertilization, and thus, nitrification was the dominant process for $\mathrm{N}_{2} \mathrm{O}$ and $\mathrm{NO}$ emissions during these periods. Considering the significant amount $(>80 \%)$ of $\mathrm{N}_{2} \mathrm{O}$ and $\mathrm{NO}_{x}$ emissions occurred during the pulse emission periods, the emissions of $\mathrm{NO}_{\mathrm{x}}$ and $\mathrm{N}_{2} \mathrm{O}$ from the investigated field were mainly ascribed to nitrification process.
\end{abstract}

(c) 2010 Elsevier Ltd. All rights reserved.

\section{Introduction}

Nitrous oxide $\left(\mathrm{N}_{2} \mathrm{O}\right)$, nitrogen oxides $\left(\mathrm{NO}_{\mathrm{x}}\right)$ and ammonia $\left(\mathrm{NH}_{3}\right)$ in the atmosphere play important roles in regional and global environment. $\mathrm{N}_{2} \mathrm{O}$ is one of the important greenhouse gases and participates in the depletion of stratospheric ozone (Crutzen, 1970; Cicerone, 1987; IPCC, 2001). $\mathrm{NO}_{\mathrm{x}}$ is a major precursor of atmospheric photo-oxidants and has important contribution to acid deposition and tropospheric ozone (Crutzen, 1979). $\mathrm{NH}_{3}$, the most abundant alkaline constituent in the atmosphere, regulates the atmospheric acidity (Brasseur et al., 1999) and soil acidification (Roclofs et al., 1987). Agricultural field has become one of the major anthropogenic sources for atmospheric $\mathrm{N}_{2} \mathrm{O}, \mathrm{NO}_{\mathrm{x}}$ and $\mathrm{NH}_{3}$ (Khalil et al., 2006) and they are mainly from fertilization (Jambert et al., 1997; Bouwman et al., 2002a; Sehy et al., 2003; Khalil et al., 2006; Li and Wang, 2007, 2008). The current estimation of $\mathrm{N}_{2} \mathrm{O}$ emission from agriculture soil to the global budget ranges from 0.11 to $6.3 \mathrm{Tg} \mathrm{N} \mathrm{yr}^{-1}$ (Mosier et al., 1998; Bouwman et al., 2002b), of NO

\footnotetext{
* Corresponding author. Tel.: +86 10 62849125; fax: +86 1062849117

E-mail address: yjmu@rcees.ac.cn (Y. Mu).
}

emission from soil varies from 4 to $21 \mathrm{Tg} \mathrm{N} \mathrm{yr}^{-1}$ (Yienger and Levy, 1995; Davidson and Kingerlee, 1997; Lee et al., 1997; Yan et al., 2005), and of $\mathrm{NH}_{3}$ emission from agricultural field accounts for $\sim 23 \%$ of global $\mathrm{NH}_{3}$ emission (Bouwman et al., 2002a). The large uncertainties of the estimations were mainly due to the spatialtemporal variations of their emissions from agricultural field.

The North China Plain (NCP) occupies an agricultural area of about $300,000 \mathrm{~km}^{2}$, accounting for $23 \%$ of Chinese cropland area (Ding et al., 2007). About 30\% of the national fertilizer is being applied in this region for maintaining the high crop yield (Zhang et al., 2004). The amount of chemical $\mathrm{N}$ fertilizer applied to the region also greatly stimulates $\mathrm{N}_{2} \mathrm{O}, \mathrm{NO}_{\mathrm{x}}$ and $\mathrm{NH}_{3}$ emissions (Walsh, 2001; Dong et al., 2001, 2007; Cai et al., 2002; Zhang et al., 2004; Wang et al., 2004; Meng et al., 2005; Ding et al., 2007). To our knowledge, most of the studies in this region mainly focused on $\mathrm{N}_{2} \mathrm{O}$ emission, and only one and three studies investigated $\mathrm{NO}$ exchange (Walsh, 2001) and $\mathrm{NH}_{3}$ volatilization (Cai et al., 2002; Zhang et al., 2004; Wang et al., 2004), respectively. Because the emissions of the three nitrogen compounds from agricultural field are closely interrelated (Cabrera et al., 1991; Khalil et al., 2006; Firestone and Davidson, 1989), simultaneous measurements of the three nitrogen compounds can provide valuable information 
about their formation processes. As for the data of $\mathrm{N}_{2} \mathrm{O}$, the large differences of fertilizer loss rates (ranging from $0.006 \%$ to $1.94 \%$ ) and average fluxes (ranging from 4.21 to $74.6 \mathrm{ng} \mathrm{N} \mathrm{m}^{-2} \mathrm{~s}^{-1}$ ) from the agricultural field of the NCP indicate that further field measurements are still needed.

In this study, $\mathrm{N}_{2} \mathrm{O}, \mathrm{NO}_{\mathrm{x}}$ and $\mathrm{NH}_{3}$ exchange fluxes from a maize field in the NCP during the whole growing period were simultaneously investigated in 2009, and the originations and environmental implications of the three nitrogen compounds from the field were also discussed.

\section{Materials and methods}

\subsection{Experimental site and field treatments}

The field experiments were carried out in an agricultural field $\left(38^{\circ} 71^{\prime} \mathrm{N}, 115^{\circ} 15^{\prime} \mathrm{E}\right)$ in Wangdu County, Hebei Province, China. Winter wheat (Triticum aestivum L.) and summer maize (Zea mays L.) have been cultivated for several decades in the field. The soil is classified as aquic inceptisol with a sandy loam texture. The soil $\mathrm{pH}$ (in a 1:2.5 soil to water), organic $\mathrm{C}$ and total $\mathrm{N}$ were 8.1, $8.34-9.43 \mathrm{~g} \mathrm{~kg}^{-1}$ and $1.02-1.09 \mathrm{~g} \mathrm{~kg}^{-1}$, respectively. This field is located in the northern part of the NCP with annual mean rainfall of about $555 \mathrm{~mm}$ and annual mean temperature of about $12.3^{\circ} \mathrm{C}$. The highest and lowest monthly mean air temperatures are $26.5^{\circ} \mathrm{C}$ in July and $-4.1^{\circ} \mathrm{C}$ in January, respectively.

The investigated field with total area of $68 \mathrm{~m}^{2}$ was divided into three $6.5 \times 3.5 \mathrm{~m}^{2}$ plots, including control (CK, without crop, fertilization and irrigation), fertilizer N (NP) and wheat straw returning plus fertilizer N (SN) treatments. Each plot was separated by plastic boards which were inserted into the soil about 0.5 meter depth. Maize was sown on June 29, 2009. Compound fertilizer ( $412 \mathrm{~kg} \mathrm{ha}^{-1}$, $\mathrm{N}: \mathrm{P}_{2} \mathrm{O}_{5}: \mathrm{K}_{2} \mathrm{O}=24 \%: 12 \%: 6 \%$ ) was broadcast to the NP and SN plots as basal fertilizer and air-dried wheat straw (4.3 tha ${ }^{-1}, \mathrm{~N}=0.48 \%, \mathrm{C}$ : N ratio $=96.9$ : 1 ) was also applied as basal fertilizer to the SN treatment. Urea ( $150 \mathrm{~kg} \mathrm{ha}^{-1}, \mathrm{~N}=46.2 \%$ ) was broadcast to NP and SN plots as supplementary fertilizer on 1 August in 2009. Flooding irrigation was carried out immediately after the basal fertilizers application, while the field was not irrigated after the supplementary fertilization because of strong rain events with cumulative rainfall of $\sim 25 \mathrm{~mm}$ both before and after the fertilizer application. Maize was harvested on 7 October. All above field management was strictly according to the cultivating manner of local farmers.

\subsection{Measurements and analysis of $\mathrm{N}_{2} \mathrm{O}, \mathrm{NO}_{x}$ and $\mathrm{NH}_{3}$}

$\mathrm{N}_{2} \mathrm{O}$ flux was measured by static chambers. Seven identical static chambers made of Plexiglas $\left(60 \times 60 \times 90 \mathrm{~cm}^{3}\right)$ were applied to cover corresponding pedestals which were inserted into the soils of the three plots at a depth of $10 \mathrm{~cm}$ during the whole maize growing season. The pedestal made of stainless steel had a gutter around its upper rim to permit water to seal with the chamber during flux measurements. Two fans were fixed at opposite position in the middle of each chamber for mixing the air in the chamber evenly. In order to reduce solar heating and greenhouse effect in the chamber, three sides (the top side and the sides towards south and east) of the chambers were covered by aluminum foils. The daily fluxes were measured from 9:30 a.m. to 10:30 a.m. (Beijing time). Five campaigns were designed for field flux measurements: 12 days from June 28 to July 9, 8 days from July 30 to August 6, 9 days from August 25 to September 2,12 days from September 10 to 21, and 1 day on October 11. Four air samples were collected into polyethylenecoated aluminum bags (Delin, Dalian, China) by a mini-pump (NMP $830 \mathrm{KNDC}$, Germany) at 10-min intervals after the chambers being enclosed $(0,10,20$ and $30 \mathrm{~min}) . \mathrm{N}_{2} \mathrm{O}$ concentrations were analyzed by a gas chromatography (Model SP3410, Beijing Analytical Instrument Factory) with an electron capture detector (ECD). Gas samples were loaded into a $2 \mathrm{~mL}$ loop connected to a 10 -port valve that is used for injecting sample to GC and back flushing a pre-column. The pre-column and an analytical column were made of stainless steel with the same size $(2 \mathrm{~m} \times 4 \mathrm{~mm})$ and packed with Porapak Q (80-100 mesh). High purity of $\mathrm{N}_{2}(99.999 \%)$ was used as carrier gas for both the columns with flow rates of $30 \mathrm{~mL} \mathrm{~min}^{-1}$. In order to improve the instrument sensitivity, a makeup gas ( 979 ppmv $\mathrm{CO}_{2}$ in $\mathrm{N}_{2}$ ) was introduced into the downstream of the analytical column with a flow rate of $8 \mathrm{~mL} \mathrm{~min}^{-1}$, and the $\mathrm{N}_{2} \mathrm{O}$ signal increased at least 4 times after the introduction of $\mathrm{CO}_{2}$. Zheng et al. (2008) pointed out that the use of $\mathrm{N}_{2}$ as the carrier gas led to significant overestimate of $\mathrm{N}_{2} \mathrm{O}$ emissions due to influence of $\mathrm{CO}_{2}$ accumulation in static chamber enclosures. However, no influence of $\mathrm{CO}_{2}$ concentration (200-2000 ppmv) in the air samples on $\mathrm{N}_{2} \mathrm{O}$ quantification was found by our improved method. The variation coefficient of our method for analyzing $\mathrm{N}_{2} \mathrm{O}$ was less than $0.31 \%$ based on the reproducibility of a $\mathrm{N}_{2} \mathrm{O}$ standard gas (358 ppbv, Center of Standard Reference Materials, Beijing, China) within $9 \mathrm{~h}$. The $\mathrm{N}_{2} \mathrm{O}$ fluxes were calculated based on the change rate of $\mathrm{N}_{2} \mathrm{O}$ concentrations with time in the chambers, and the correlation coefficients were always greater than 0.95 .

$\mathrm{NO}_{\mathrm{x}}$ and $\mathrm{NH}_{3}$ fluxes were measured by dynamic chamber technique. Each dynamic chamber (32 cm diameter, $80 \mathrm{~cm}$ height) consisted of a chamber cap and a pedestal. The chamber caps were made of stainless steel bracket which was wrapped with Teflon film. Seven inlets ( $10 \mathrm{~mm}$, I.D.) are evenly distributed on the top of each chamber cap and six outlets ( $3 \mathrm{~mm}$, I.D.) are evenly connected with the chamber cap at about $10-\mathrm{cm}$ above its bottom. The pedestals made of stainless steel were always inserted into the soils about $10-\mathrm{cm}$ depth of the three treatments during the whole maize growing period. Water was added to the channel along the pedestals' upper rim to make airtight seal with the chamber cap during flux measurements. Six mini-pump (NMP 830 KNDC, Germany) simultaneously pumped air from the outlets to flush the chambers with total flow rate of about $15 \mathrm{~L} \mathrm{~min}^{-1}$ during sampling. To eliminate the possible loss of $\mathrm{NO}_{\mathrm{x}}$ and $\mathrm{NH}_{3}$ on the wall of the chamber, a chamber with bottom covered with Teflon film was used as reference chamber. $\mathrm{NO}_{\mathrm{x}}$ and $\mathrm{NH}_{3}$ fluxes were derived from the concentrations' differences of $\mathrm{NO}_{\mathrm{x}}$ and $\mathrm{NH}_{3}$ at the outlets between the sampling chamber and reference chamber. Two air samples from each chamber were collected into Teflon bags ( $2 \mathrm{~L}$ in volume each) when the concentrations of $\mathrm{NO}_{\mathrm{x}}$ and $\mathrm{NH}_{3}$ reached steady state (at $15 \mathrm{~min}$, more than 2 flushing cycles), and analyzed immediately in the field laboratory. The daily sampling time was from 15:00 p.m. to 17:00 p.m. (Beijing time). $\mathrm{NO}_{\mathrm{x}}$ and $\mathrm{NH}_{3}$ concentrations were analyzed by a chemiluminescent $\mathrm{NH}_{3}$ analyzer (Thermo Electron model 17i, USA). The instrument was calibrated by BML-Dynamic Dilution Calibrator System before transported to the field, and further calibrated in the field before every campaign according to following procedure: purified air (through a trap filled silica gel and active carbon) with $\mathrm{NO}_{\mathrm{x}}$ and $\mathrm{NH}_{3}$ concentrations around their detection limits was continually passing through the instrument as background, and seven concentrations respectively for $\mathrm{NH}_{3}$ and $\mathrm{NO}$ in $2 \mathrm{~L}$ Teflon bags prepared by dilution standard gases (Center of Standard Reference Materials, Beijing, China) were injected into the instrument by switching a 3-way valve between the trap and the inlet of the instrument. Good linear correlations $\left(R^{2} \geq 0.998\right)$ between the actual values and the measured values were observed in every calibration for $\mathrm{NO}$ and $\mathrm{NH}_{3}$, respectively.

The maize distances between rows and between hills were $50 \mathrm{~cm}$ and $30 \mathrm{~cm}$, respectively. The pedestals of the static chambers and dynamic chambers covered four maize crops and one crop, respectively. The top parts of the maize in the pedestals were cut off 
on 24 August 2009 for fitting the size of the chamber. The flux measurements had three duplicates for each plot with the relative standard deviations (RSD) generally less than $60 \%$, and only the average fluxes were presented in this study. During sampling period, soil temperature at $10-\mathrm{cm}$ depth and air temperature inside the chambers were simultaneously recorded.

\subsection{Soil sampling and analysis}

Soil samples were collected 1-2 times during each sampling campaign. Two soil samples randomly removed by a ring sampler ( $5 \mathrm{~cm}$ I.D. $\times 5 \mathrm{~cm}$ Height) from $0-5 \mathrm{~cm}$ topsoil of each plot were used for the water-filled pore space (WFPS) analysis and four soil samples from the $0-10 \mathrm{~cm}$ layer gathered by a trowel were used for analyzing soil $\mathrm{NH}_{4}^{+}-\mathrm{N}$ and $\mathrm{NO}_{3}^{-}-\mathrm{N}$. Soil moisture was determined by drying the soil at $105^{\circ} \mathrm{C}$ for $12 \mathrm{~h}$. WFPS was calculated by dividing the volumetric water content by total soil porosity. Total soil porosity was calculated according to the relationship: soil porosity $=(1-$ soil bulk density/2.65), assuming a particle density of $2.65 \mathrm{~g} \mathrm{~cm}^{-3}$. $\mathrm{NH}_{4}^{+}-\mathrm{N}$ and $\mathrm{NO}_{3}^{-}-\mathrm{N}$ contents were measured by a colorimetric continuous flow analyzer (SANT ++ , Skalar Company, the Netherlands).

\subsection{Data analysis}

The data analysis was performed using SPSS 13.0 software (SPSS Inc., Chicago, USA) and Origin 7.5 (Origin Lab Corporation, USA). Cumulative $\mathrm{N}_{2} \mathrm{O}, \mathrm{NO}, \mathrm{NO}_{2}$ and $\mathrm{NH}_{3}$ emissions from each plot were integrated based on sampling date. It is assumed that the emissions were followed a constant flux rate (the average rate between two sampling date) during the periods when no samples were taken.

\section{Results and discussions}

\section{1. $\mathrm{N}_{2} \mathrm{O}$ exchange fluxes}

$\mathrm{N}_{2} \mathrm{O}$ emissions increased quickly after one day of fertilizer applications, and the highest emission rate was about $140 \mathrm{ng} \mathrm{N} \mathrm{m}^{-2} \mathrm{~s}^{-1}$ after 6 days of the basal fertilizer application and 4 days of the supplementary fertilization in the NP and SN plots (Fig. 1a). The duration of $\mathrm{N}_{2} \mathrm{O}$ emission induced by fertilization was about 10 days. The average $\mathrm{N}_{2} \mathrm{O}$ emission fluxes (mean $\pm \mathrm{SE}$ ) from $\mathrm{NP}$ and SN plots were $30.0 \pm 3.1 \mathrm{ng} \mathrm{N} \mathrm{m}^{-2} \mathrm{~s}^{-1}$ and $35.0 \pm 3.4 \mathrm{ng} \mathrm{N}$ $\mathrm{m}^{-2} \mathrm{~s}^{-1}$ (mean $\pm \mathrm{SE}, n=106$ ), respectively. Fertilizer loss rates as $\mathrm{N}_{2} \mathrm{O}-\mathrm{N}$ were $1.08 \%$ and $1.20 \%$, respectively.

An extremely high $\mathrm{N}_{2} \mathrm{O}$ emission (312 $\mathrm{ng} \mathrm{N} \mathrm{m}^{-2} \mathrm{~s}^{-1}$ ) occurred in the CK plot after a rain event with rainfall of about $12 \mathrm{~mm}$ on 8 July. Because of consecutive sunny days lasted for more than 15 days before the rain event, the soil in the CK plot became extremely dry (WFPS $<20 \%$ ) due to no shield of plant canopy. The extremely high $\mathrm{N}_{2} \mathrm{O}$ emission from the CK plot on the day was ascribed to the rewetting of the extremely dry soil (Jørgensen et al., 1998). Each $\mathrm{N}_{2} \mathrm{O}$ pulse from $\mathrm{CK}$ plot during later cases was also corresponding to a rain event, but $\mathrm{N}_{2} \mathrm{O}$ emission strength was much lower than that of the first case, which was probably due to the higher soil water content (WFPS > 40\%) during the later rain events. Compared with CK plot, the shield of the maize canopy on the two fertilization plots would largely reduce the influence of the small rain events on wetting the soil, and hence, only two pulse emissions corresponded to the two rain events on 8 July and 5-6 August were observed. These pulse emissions were probably due to effects of fertilization, because these dates were just after several days of fertilizer application.
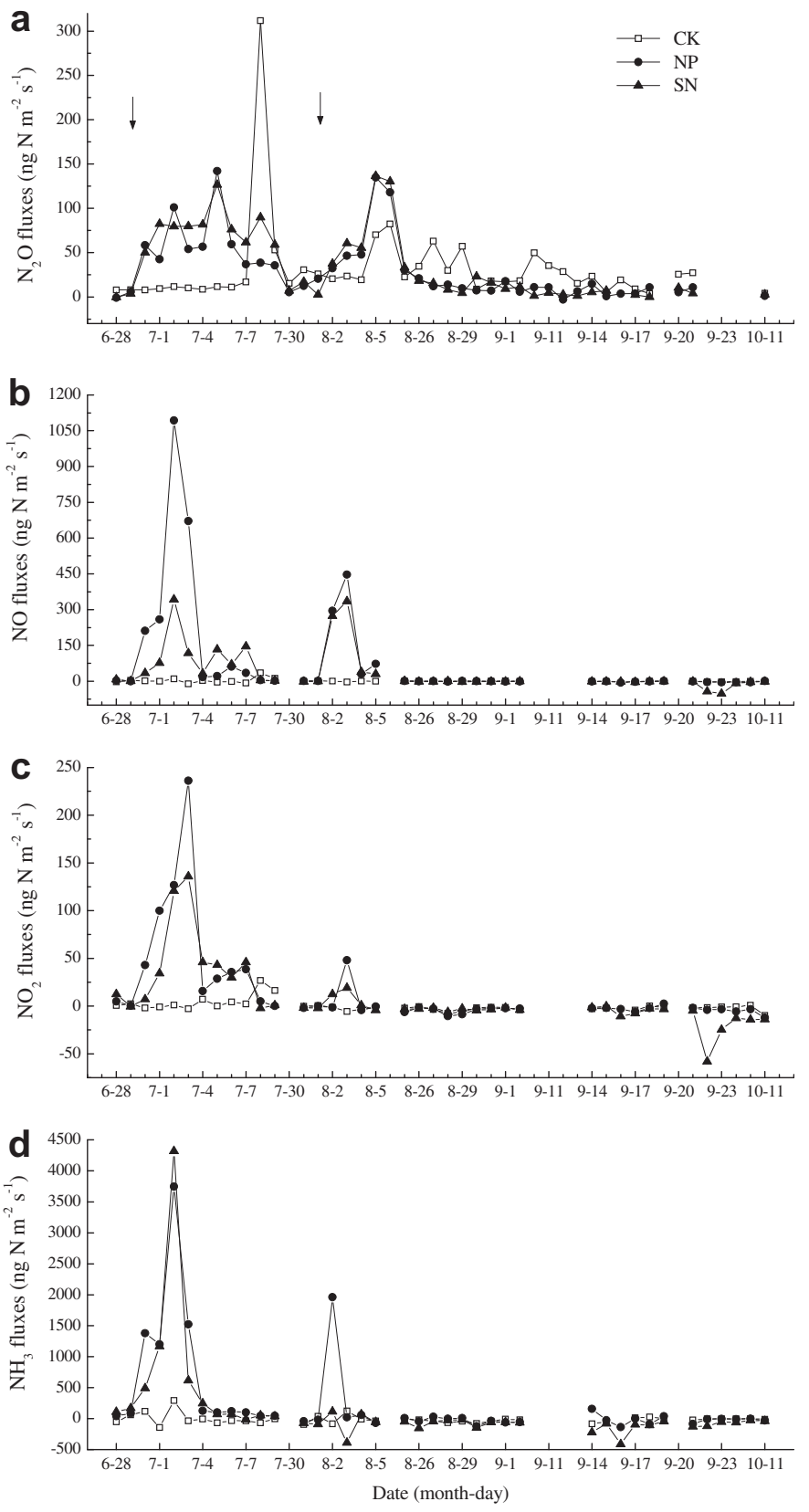

Fig. 1. Variations of $\mathrm{N}_{2} \mathrm{O}$ (a), $\mathrm{NO}$ (b), $\mathrm{NO}_{2}$ (c) and $\mathrm{NH}_{3}$ (d) fluxes from the three treatments during the maize growing period. Arrows show fertilizer applications.

\section{2. $\mathrm{NO}_{x}$ exchange fluxes}

$\mathrm{NO}_{\mathrm{x}}$ emissions from the NP and SN plots also increased quickly just after $\mathrm{N}$-fertilizer application, and the duration of the pulse emission induced by basal fertilization was also about 10 days (Fig. $1 \mathrm{~b}, \mathrm{c}$ ). However, $\mathrm{NO}_{\mathrm{x}}$ emission peaks after the two fertilizations were about two days earlier than those of $\mathrm{N}_{2} \mathrm{O}$ emission. The highest NO emission rate $\left(\sim 1100 \mathrm{ng} \mathrm{N} \mathrm{m}^{-2} \mathrm{~s}^{-1}\right)$ from the NP plot was about 3 times higher than that $\left(340 \mathrm{ng} \mathrm{N} \mathrm{m}^{-2} \mathrm{~s}^{-1}\right.$ ) from SN plot after the basal fertilization, whereas, there was no significant difference between the two plots after the supplementary fertilizer application $\left(\sim 350 \mathrm{ng} \mathrm{N} \mathrm{m}^{-2} \mathrm{~s}^{-1}\right)$. The possible reason was that the fresh wheat straw in the SN plot could consume oxygen in the soil, and NO formed in the soil was easily consumed by denitrifiers (Conrad, 1996). The wheat straw had become rotten when the 
supplementary fertilizer application and its influence on soil oxygen became less accordingly. Several investigators found the burst of NO emission when dry soil becomes wet (Scholes et al., 1997; Martin et al., 1998), and this effect of soil moisture change on NO emission has been incorporated into the statistical and empirical models for estimating NO emission from soils (Yienger and Levy, 1995; Yan et al., 2005). However, contrasting with $\mathrm{N}_{2} \mathrm{O}$ emission, only a small pulse emission (from -7.85 to $34.6 \mathrm{ng} \mathrm{N} \mathrm{m}^{-2} \mathrm{~s}^{-1}$ ) of NO from the CK plot was observed after the rain event on 8 July. The possible reason for this phenomenon was that denitrification was probably the dominant process during re-wetting of the dry soil and contributed the extremely high $\mathrm{N}_{2} \mathrm{O}$ emission, while NO emission is mainly from the nitrification (Davidson, 1992).

The average NO fluxes were $1.08 \pm 0.46,36.5 \pm 13.2$ and $16.7 \pm$ $5.67 \mathrm{ng} \mathrm{N} \mathrm{m}^{-2} \mathrm{~s}^{-1}$ for CK, NP and SN plots, respectively. Fertilizer loss rates as NO-N were $1.93 \%$ and $0.76 \%$ for the NP and SN plots, respectively. It is evident that straw returning to the field could greatly reduce NO emission ( $\sim 54 \%)$. The NO loss rates obtained by this study were in the range of different types of soils with different plants $(0.003 \%-11 \%$, Yan et al., 2003$)$.

Evident $\mathrm{NO}_{2}$ emissions were only observed from the NP and SN plots after fertilizations. Significant correlation between NO and $\mathrm{NO}_{2}$ fluxes $(R=0.67-0.81, N=38, P<0.01)$ were found for the three plots, which indicated that $\mathrm{NO}_{2}$ emissions were mainly ascribed to photochemical conversion of $\mathrm{NO}$ to $\mathrm{NO}_{2}$ in the dynamic chamber. The average $\mathrm{NO}_{2}$ fluxes during the maize growing period (late June-October) were $0.81 \pm 0.52,4.13 \pm 2.84$ and $0.22 \pm 2.13$ ng $\mathrm{N} \mathrm{m}^{-2} \mathrm{~s}^{-1}$ for CK, NP and SN plots, respectively.

\section{3. $\mathrm{NH}_{3}$ exchange fluxes}

Two evident emission peaks of $\mathrm{NH}_{3}$ were observed on 2 July from the NP and SN plots and on 2 August from NP plot (Fig. 1d). Differing from $\mathrm{NO}$, the first $\mathrm{NH}_{3}$ emission peaks from the two plots were almost identical and the second $\mathrm{NH}_{3}$ emission peak with oneday duration was only observed from the NP plot. The relatively low $\mathrm{NH}_{3}$ emission after the supplementary fertilization from the SN plot was coincident with the relatively low $\mathrm{NH}_{4}^{+}$concentration in the soil (data not shown). In addition, the duration of the $\mathrm{NH}_{3}$ pulse emissions induced by basal fertilization was about three days later than those of $\mathrm{N}_{2} \mathrm{O}$ and $\mathrm{NO}$. The average $\mathrm{NH}_{3}$ fluxes were $-23.8 \pm 4.56,94.0 \pm 45.3$ and $15.2 \pm 44.1 \mathrm{ng} \mathrm{N} \mathrm{m}^{-2} \mathrm{~s}^{-1}$ for CK, NP and $\mathrm{SN}$ plots, respectively. It is evident that straw returning to the field could also greatly reduce $\mathrm{NH}_{3}$ emission ( $84 \%$ ).

With exception of the pulse emissions induced by fertilization, the investigated field always acted as a small sink for atmospheric $\mathrm{NH}_{3}$. The fertilizer loss rates as $\mathrm{NH}_{3}-\mathrm{N}$, therefore, were calculated only based on the data during the two emission periods (30 June-7 July for basal fertilizer application and 2-5 August for supplementary fertilizer application) as 5.24\% and 3.03\% for the NP and SN plots, respectively. Compared with the basal fertilizer application, the significantly low $\mathrm{NH}_{3}$ emission after the supplementary fertilizer application indicated that the maize crop could absorb large proportion of $\mathrm{NH}_{3}$ emitted from the soil.

\subsection{Origins of $\mathrm{N}_{2} \mathrm{O}, \mathrm{NO}_{x}$ and $\mathrm{NH}_{3}$ emissions}

The formation processes for $\mathrm{N}_{2} \mathrm{O}, \mathrm{NO}_{\mathrm{x}}$ and $\mathrm{NH}_{3}$ in agricultural soils have been recognized to be nitrification, denitrification, and ammonification. However, the detail information (especially for $\mathrm{N}_{2} \mathrm{O}$ and $\mathrm{NO}_{\mathrm{x}}$ ) about the dominant process in most agricultural fields is still unclear. The ratio of $\mathrm{NO} / \mathrm{N}_{2} \mathrm{O}$ is being used as a potential methodology for distinguishing soil nitrification and denitrification (Anderson and Levine, 1986; Williams et al., 1998; Meijide et al., 2007). Anderson and Levine (1986) found the molar ratio of $\mathrm{NO} /$
$\mathrm{N}_{2} \mathrm{O}$ was usually greater than unity for nitrifiers and much less than unity for denitrifiers. From field measurements, however, Meijide et al. (2007) found the predominance of nitrification occurred when $\mathrm{NO} / \mathrm{N}_{2} \mathrm{O}>0.11$. As for our data, the ratios of $\mathrm{NO} / \mathrm{N}_{2} \mathrm{O}$ from $\mathrm{NP}$ and SN treatments less than unity were both $68 \%$, and less than 0.11 accounted for $53 \%$ and $59 \%$, respectively. As for the CK plot, $79 \%$ of $\mathrm{NO} / \mathrm{N}_{2} \mathrm{O}$ ratios were less than 0.11 . The higher percentage of $\mathrm{NO} /$ $\mathrm{N}_{2} \mathrm{O}<0.11$ in the SN plot than that in the NP plot was ascribed to the wheat straw consuming oxygen in the SN plot, which was in favor of denitrification. The significantly less percentage of $\mathrm{NO} /$ $\mathrm{N}_{2} \mathrm{O}<0.11$ in the NP and SN plots than that in the CK plot was mainly due to fertilizations. Therefore, $\mathrm{N}_{2} \mathrm{O}$ emissions during most of the maize growing period might be dominated by denitrification. Because the largest proportions of $\mathrm{N}_{2} \mathrm{O}(>80 \%)$ and $\mathrm{NO}(>95 \%)$ emitted from the NP and SN plots during the periods after fertilization when the ratios of $\mathrm{NO} / \mathrm{N}_{2} \mathrm{O}$ were more than unity (Fig. 2), nitrification greatly contributed to $\mathrm{NO}$ and $\mathrm{N}_{2} \mathrm{O}$ emissions from the investigated maize field.

Anderson and Levine (1986) found $\mathrm{N}_{2} \mathrm{O}$ emissions depend upon the competition between nitrite and oxygen for electrons removing from ammonium during nitrification, with more $\mathrm{N}_{2} \mathrm{O}$ production via nitrite reduction. The extremely high $\mathrm{NH}_{3}$ emissions just after fertilization indicated that large amounts of ammonium were formed in the soil. The formed ammonium might greatly consume oxygen absorbed in the soil, and nitrite consumption dominated for $\mathrm{N}_{2} \mathrm{O}$ formation, which might be the reason why $\mathrm{N}_{2} \mathrm{O}$ emission peaks appeared two days later than those of $\mathrm{NH}_{3}$ and $\mathrm{NO}$.

\subsection{Comparison with previous studies in the NCP}

\subsection{1. $\mathrm{N}_{2} \mathrm{O}$ emission}

Among the investigations of $\mathrm{N}_{2} \mathrm{O}$ emission from maize field in the $\mathrm{NCP}$, the large difference was $\mathrm{N}_{2} \mathrm{O}$ emission strength (especially for the peak emissions), e.g. the peak value obtained in this study was about a factor of 2-3 higher than those reported by Zhang et al. (2004) and Dong et al. (2001), but it was about 40\% lower than the data recently reported by Ding et al. (2007) with similar fertilization level as ours. This difference was mainly ascribed to the large spatial-temporal variation. In addition, the sampling frequency also affected the observed peak values due to significant daily variation of $\mathrm{N}_{2} \mathrm{O}$ emission after fertilization. The sampling frequencies for most studies in the NCP were only once or twice per week, which would result in large uncertainty for estimating $\mathrm{N}_{2} \mathrm{O}$ emission from the maize field, e.g. the cumulative $\mathrm{N}_{2} \mathrm{O}$ emission ( $\mathrm{SN}$ plot, $3.21 \mathrm{~kg} \mathrm{~N} \mathrm{ha}^{-1}$ ) investigated in this study was similar to the value

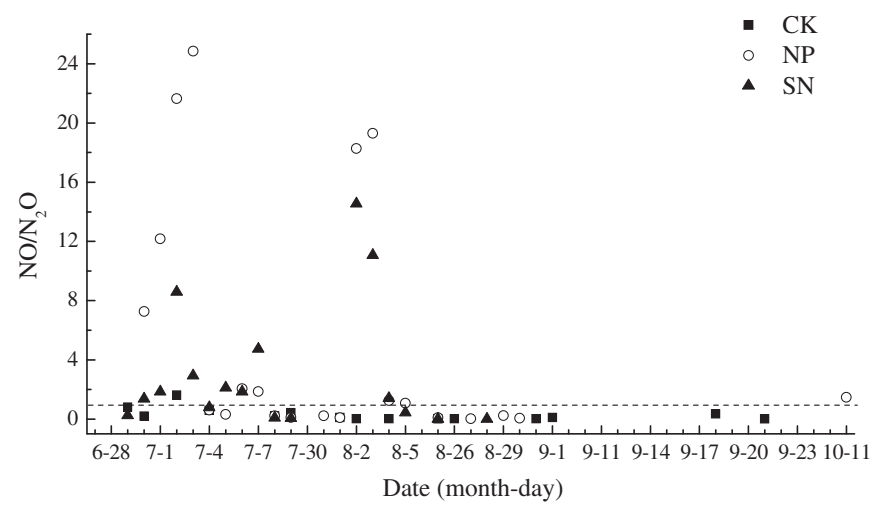

Fig. 2. Molar $\mathrm{NO} / \mathrm{N}_{2} \mathrm{O}$ ratios from $\mathrm{NP}$ and $\mathrm{SN}$ plots during the maize growing period. The intercept of the dash line on the $Y$-axis represents the molar ratio of $\mathrm{NO} / \mathrm{N}_{2} \mathrm{O}$ equated to unity. 
(3.78 $\mathrm{kg} \mathrm{N} \mathrm{ha}^{-1}$ ) reported by Ding et al. (2007), though our peak values were about $40-80 \%$ lower than theirs.

\subsubsection{NO exchange fluxes}

To our knowledge, only Walsh (2001) studied NO exchange fluxes at China agricultural University (Beijing) for seven weeks from May to June. The mean NO fluxes from the two fertilization plots (NP: $36.5 \pm 13.2 \mathrm{ng} \mathrm{N} \mathrm{m}^{-2} \mathrm{~s}^{-1}$, SN: $16.7 \pm 5.67 \mathrm{ng} \mathrm{N} \mathrm{m}^{-2} \mathrm{~s}^{-1}$ ) in this study were lower than that $\left(77.5 \pm 65 \mathrm{ng} \mathrm{N} \mathrm{m}^{-2} \mathrm{~s}^{-1}\right)$ reported by Walsh (2001), but fertilizer loss rates as NO-N (0.76-1.93\%) were closed to his $(0.75-1.6 \%)$. In the study of Walsh (2001), several NO emission peaks were observed after fertilization with the maximal peak about 10 days after fertilizations. In this study, however, the only one obvious NO emission peak after each fertilization case from the two treatments occurred about two days after fertilizations.

\subsection{3. $\mathrm{NH}_{3}$ volatilization}

Only three reports about $\mathrm{NH}_{3}$ volatilization in the NCP are available in the literature. The three reports and ours revealed that $\mathrm{NH}_{3}$ volatilization from maize field increased quickly after fertilizations with peak emissions around 1-4 days after fertilizations and the duration of the pulse emission induced by fertilization was usually less than 7 days. However, the emission strengths investigated by different groups were largely variable. The peak value (e.g. $3744 \mathrm{ng} \mathrm{N} \mathrm{m}^{-2} \mathrm{~s}^{-1}$ for NP plot) after basal fertilizer application in this study was about a factor of 1.5 less than that reported by Cai et al. (2002) with fertilizer rate of $75 \mathrm{~kg} \mathrm{~N} \mathrm{ha}^{-1}$, and 3.2-fold less than that reported by Zhang et al. (2004) with fertilizer rate of $157 \mathrm{~kg} \mathrm{Nha}^{-1}$, and 1.0-1.8 times higher than those reported by Wang et al. (2004) with fertilization rates of $60-120 \mathrm{~kg} \mathrm{~N} \mathrm{ha}^{-1}$. The extremely high $\mathrm{NH}_{3}$ emission from the maize field studied by Zhang et al. (2004) was mainly due to high fertilization rate that was about 1.6 times higher than ours. As for the supplementary fertilization, only Wang et al. (2004) conducted similar experiment as ours. The peak of $\mathrm{NH}_{3}$ emission (1961 $\mathrm{ng} \mathrm{N} \mathrm{m}^{-2} \mathrm{~s}^{-1}$, NP plot) in this study was about 1.5 times less than that reported by Wang et al. (2004) with the same fertilization rate. It should be mentioned the vented-chamber without crop used by Wang et al. (2004) would greatly overestimated $\mathrm{NH}_{3}$ emission during this period, because a large proportion of $\mathrm{NH}_{3}$ emitted from soil could be re-absorbed by crop via stomata (Jones et al., 2007). The fertilizer loss rates as $\mathrm{NH}_{3}-\mathrm{N}$ of $3.03 \%-5.24 \%$ from the two treatments after basal and supplementary fertilization in this study were much less than $22.6 \%$ reported by Zhang et al. (2004) and $18 \%$ reported by Cai et al. (2002), and closed to the values (3.2-6.3\%) reported by Wang et al. (2004).

\subsection{Environmental implications}

Maize is cultivated in this region during June-September when the photochemical reactions are the most active. Because the formation of photochemical oxidants (such as $\mathrm{O}_{3}$ ) in rural areas is usually limited by $\mathrm{NO}_{\mathrm{x}}$ (Aneja et al., 1996), the strong NO pulse emissions induced by fertilizations would greatly elevate atmospheric $\mathrm{O}_{3}$ level over a large region, which can impact on the air quality of the metropolis (such as Beijing and Tianjin) in this region because of the elevation of background concentration by long distance transportation. To effective mitigate $\mathrm{O}_{3}$, in the viewpoint of the authors, reduction of $\mathrm{NO}_{\mathrm{x}}$ emission from the agricultural field in the NCP should be considered.

A large fraction of the emitted $\mathrm{NH}_{3}$ from the maize field in this region can be quickly converted to ammonium as fine particles via heterogeneous reactions on acid particles or photochemical reactions. The fine particle of ammonium is readily soluble, and can greatly reduce atmospheric visibility via absorption of atmospheric water vapor. Although the duration of the pulse $\mathrm{NH}_{3}$ emission induced by fertilizer only lasted for several days, the long lifetime of atmospheric ammonium in the fine particles can maintain the influence on environment for much longer time and over larger region. The high frequency of haze day in the NCP in recent years is closely relating to the high concentration of fine particles in which ammonium accounted for the largest proportion of the total cations (Sun et al., 2006). Zhang et al. (2010) recently calculated agricultural ammonia emissions inventory in the NCP, and found that $54 \%$

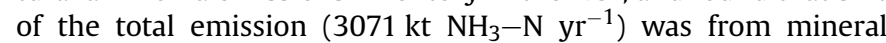
fertilizer application. Therefore, to improve the air quality in the $\mathrm{NCP}$, mitigating $\mathrm{NH}_{3}$ emission from the agricultural field in this region is urgently needed.

\section{Conclusion}

The current $\mathrm{N}$-fertilizers (compound fertilizer and urea) used in the $\mathrm{NCP}$ could greatly stimulate $\mathrm{N}_{2} \mathrm{O}, \mathrm{NO}_{\mathrm{x}}$ and $\mathrm{NH}_{3}$ emissions from the maize field. The molar ratio of $\mathrm{NO} / \mathrm{N}_{2} \mathrm{O}$ indicated that $\mathrm{N}_{2} \mathrm{O}$ and NO emissions from the field was mainly dominated by denitrification during the most maize growing period, while nitrification during the pulse emission periods made the largest contribution for their total emissions. The strong pulse $\mathrm{NO}_{\mathrm{x}}$ and $\mathrm{NH}_{3}$ emissions from the field had important influence on the regional air quality. To improve the air quality in the big cities such as Beijing and Tianjin, the agricultural sources of $\mathrm{NO}_{\mathrm{x}}$ and $\mathrm{NH}_{3}$ should be considered. Straw returning to the field should be further advocated for mitigating $\mathrm{NO}_{\mathrm{x}}$ and $\mathrm{NH}_{3}$ emissions from this region.

\section{Acknowledgements}

This work was financially supported by Special Fund for Environmental Research in the Public Interest (201009001), the Chinese National Natural Science Foundation (41075094, 40830101 and 20977097), the National Water Special Project (2008ZX07421-001 and 2009ZX07210-009), the Chinese Academy of Sciences (KZCX2YW-Q02-03), and National Basic Research and the Development Program 973 (2010CB732304).

\section{References}

Anderson, I.C., Levine, J.S., 1986. Relative rates of nitric oxide and nitrous oxide production by nitrifiers, denitrifiers and nitrate respirers. Applied and Environmental Microbiology 51, 938-945.

Aneja, V.P., Robarge, W.P., Sullivan, L.J., Moore, T.C., Pierce, T.E., Geron, C., Gay, B., 1996. Seasonal variations of nitric oxide flux from agricultural soils in the Southeast United States. Tellus 48B, 626-640.

Bouwman, A.F., Boumans, L.J.M., Batjes, N.H., 2002a. Estimation of global $\mathrm{NH}_{3}$ volatilization loss from synthetic fertilizers and animal manure applied to arable lands and grasslands. Global Biogeochemical Cycles 16, 1024.

Bouwman, A.F., Boumans, L.J.M., Batjes, N.H., 2002b. Modeling global annual $\mathrm{N}_{2} \mathrm{O}$ and NO emissions from fertilized fields. Global Biogeochemical Cycles 16, 1080

Brasseur, G.P., Orlando, J.J., Tyndall, G.S., 1999. Atomospheric Chemistry and Global Change. Oxford University Press, New York.

Cabrera, M.L., Kissel, D.E., Bock, B.R., 1991. Urea hydrolysis in soil: Effects of urea concentration and soil pH. Soil Biology \& Biochemistry 23, 1121-1124.

Cai, G., Chen, D., White, R.E., Fan, X.H., Pacholski, A., Zhu, Z.L., Ding, H., 2002. Gaseous nitrogen losses from urea applied to maize on a calcareous fluvo-aquic soil in the North China Plain. Australian Journal of Soil Research 40, 737-748.

Cicerone, R.J., 1987. Changes in stratospheric ozone. Science 237, 35-42.

Conrad, R., 1996. Soil microorganisms as controllers of atmospheric trace gases $\left(\mathrm{H}_{2}\right.$ $\mathrm{CO}, \mathrm{CH}_{4}, \mathrm{OCS}, \mathrm{N}_{2} \mathrm{O}$, and NO. Microbiological Reviews 60, 609-640.

Crutzen, P.J., 1970. The influence of nitrogen oxides on the atmospheric ozone content. Quarterly Journal of the Royal Meteorological Society 96, 320-325.

Crutzen, P.J., 1979. The role of $\mathrm{NO}$ and $\mathrm{NO}_{2}$ in the chemistry of the troposphere and stratosphere. Annual Review of Earth and Planetary Sciences 7, 443-472.

Davidson, E.A., 1992. Pulses of nitric oxide and nitrous oxide flux following wetting of dry soil: an assessment of probable sources and importance relative to annual fluxes. Ecological Bulletins 42, 149-155.

Davidson, E.A., Kingerlee, W., 1997. A global inventory of nitric oxide emissions from soils. Nutrient Cycling in Agroecosystems 48, 37-50. 
Ding, W.X., Cai, Y., Cai, Z.C., Yagi, K., Zheng, X.H., 2007. Nitrous oxide emissions from an intensively cultivated maize-wheat rotation soil in the North China Plain. Science of the Total Environment 373, 501-511.

Dong, Y., Scharffe, D., Qi, Y.C., Peng, G.B., 2001. Nitrous oxide emissions from cultivated soils in the North China Plain. Tellus 53B, 1-9.

Dong, Y.H., Ouyang, Z., Li, Y.S., Li, P., Zhang, L., 2007. Influence of different fertilization on $\mathrm{CO}_{2}$ and $\mathrm{N}_{2} \mathrm{O}$ fluxes from agricultural soil. Soil and Fertilizer Sciences in China 4, 34-39 (in Chinese).

Firestone, M.K., Davidson, E.A., 1989. Microbiological basis of $\mathrm{NO}$ and $\mathrm{N}_{2} \mathrm{O}$ production and consumption in soil. In: Andreae, M.O., Schimel, D.S. (Eds.), Exchange of the Trace Gases Between Terrestrial Ecosystems and the Atmosphere, Chichester, UK, pp. 7-21.

Intergovernmental Panel on Climate Change (IPCC), 2001. IPCC Third Assessment Report: Climate Change 2001, the Scientific Basis. Cambridge University Press, Cambridge.

Jambert, C., Serça, D., Delmas, R., 1997. Quantification of N-losses as $\mathrm{NH}_{3}, \mathrm{NO}, \mathrm{N}_{2} \mathrm{O}$ and $\mathrm{N}_{2}$ from fertilized maize fields in southwestern France. Nutrient Cycling in Agroecosystems 48, 91-104.

Jones, M.R., Leith, I.D., Raven, J.A., Fowler, D., Sutton, M.A., Nemitz, E., Cape, J.N., Sheppard, L.J., Smith, R.I., 2007. Concentration-dependent $\mathrm{NH}_{3}$ deposition processes for moorland plant species with and without stomata. Atmospheric Environment 41, 8980-8994.

Jørgensen, R.N., Jørgensen, B.J., Nielsen, N.E., 1998. $\mathrm{N}_{2} \mathrm{O}$ emission immediately afte rainfall in a dry stubble field. Soil Biology \& Biochemistry 30, 545-546.

Khalil, M.I., Schmidhalter, U., Gutser, R., 2006. $\mathrm{N}_{2} \mathrm{O}, \mathrm{NH}_{3}$ and $\mathrm{NO}_{\mathrm{x}}$ emissions as a function of urea granule size and soil type under aerobic conditions. Water Air, and Soil Pollution 175, 127-148.

Lee, D.S., Köhler, I., Grobler, E., Rohrer, F., Sausen, R., Gallardo-Klenner, L. Olivier, J.G.J., Dentener, F.J., 1997. Estimations of global $\mathrm{NO}_{\mathrm{x}}$ emissions and their uncertainties. Atmospheric Environment 31, 1735-1749.

Li, D.J., Wang, X.M., 2007. Nitric oxide emission from a typical vegetable field in the Pearl River Delta, China. Atmospheric Environment 41, 9498-9505.

Li, D.J., Wang, X.M., 2008. Nitrogen isotopic signature of soil-released nitric oxide (NO) after fertilizer application. Atmospheric Environment 42, 4747-4754.

Martin, R.E., Scholes, M.C., Mosier, A.R., Ojima, D.S., Holland, E.A., Parton, W.J., 1998 Controls on annual emissions of nitric oxide from soils of the Colorado shortgrass steppe. Global Biogeochemcal Cycles 12, 81-91.

Meijide, A., Díez, J.A., Sánchez-Martin, L., López-Fernández, S., Vallejo, A., 2007. Nitrogen oxide emissions from an irrigated maize crop amended with treated pig slurries and composts in a Mediterranean climate. Agriculture, Ecosystems and Environment 121, 383-394.

Meng, L., Ding, W.X., Cai, Z.C., 2005. Long-term application of organic manure and nitrogen fertilizer on $\mathrm{N}_{2} \mathrm{O}$ emissions, soil quality and crop production in a sandy loam soil. Soil Biology \& Biochemistry 37, 2037-2045.
Mosier, A., Kroeze, C., Nevison, C., Oenema, O., Seitzinger, S., van Cleemput, O., 1998. Closing the global $\mathrm{N}_{2} \mathrm{O}$ budget: nitrous oxide emissions through the agricultural nitrogen cycle. Nutrient Cycling in Agroecosystems 52, 225-248.

Roclofs, J.G.M., Boxman, A.W., Van Dijk, H.F.G., 1987. Effect of ammonium on natural vegetation and forest. In: Asman, W.H., Diederen, H.S.M.A. (Eds.), Ammonia and Acidification, pp. 266-276.

Scholes, M., Martin, R., Scholes, R., Parsons, D., Winstead, E., 1997. NO and $\mathrm{N}_{2} \mathrm{O}$ emissions from savanna soils following the first simulated rains of the season. Nutrient Cycling in Agroecosystems 48, 115-122.

Sehy, U., Ruser, R., Munch, J.C., 2003. Nitrous oxide fluxes from maize fields: relationship to yield, site-specific fertilization, and soil conditions. Agriculture, Ecosystems and Environment 99, 97-111.

Sun, Y.L., Zhuang, G.S., Tang, A.H., Wang, Y., An, Z.S., 2006. Chemical Characteristics of $\mathrm{PM}_{2.5}$ and $\mathrm{PM}_{10}$ in Haze-Fog Episodes in Beijing. Environmental Science \& Technology 40, 3148-3155.

Walsh, M., 2001. $\mathrm{NO}_{\mathrm{x}}$ and $\mathrm{N}_{2} \mathrm{O}$ fluxes in an upland agroecosystem of the North China Plain: field measurements, biogeochemical simulation, and climatic sensitivity. PhD dissertation, Colorado State University, Fort Collins, Colorado.

Wang, Z.H., Liu, X.J., Ju, X.T., Zhang, F.S., Malhi, S.S., 2004. Ammonia volatilization loss from surface-broadcast urea: comparison of vented- and closedchamber methods and loss in winter wheat-summer maize rotation in North China Plain. Communications in Soil Science and Plant Analysis 35, 2917-2939.

Williams, P.H., Jarvis, S.C., Dixon, E., 1998. Emission of nitric oxide and nitrous oxide from soil under field and laboratory conditions. Soil Biology \& Biochemistry 30, 1885-1893.

Yan, X.Y., Shimizu, K., Akimoto, H., Ohara, T., 2003. Determining fertilizer-induced NO emission ratio from soils by a statistical distribution model. Biology and Fertility of Soils 39, 45-50.

Yan, X.Y., Ohara, T., Akimoto, H., 2005. Statistical modeling of global soil NOx emissions. Global Biogeochemical Cycles 19, GB3019.

Yienger, J.J., Levy II, H., 1995. Empirical model of global soil-biologenic NOx emissions. Journal of Geophysical Research 100, 11447-11464.

Zhang, Y.M., Chen, D.L., Zhang, J.B., Edis, R., Hu, C.S., Zhu, A.N., 2004. Ammonia volatilization and denitrification losses from an irrigated maize-wheat rotation field in the North China Plain. Pedosphere 14, 533-540.

Zhang, Y., Dore, A.J., Ma, L., Liu, X.J., Ma, W.Q., Cape, J.N., Zhang, F.S., 2010. Agricultural ammonia emissions inventory and spatial distribution in the North China Plain. Environmental Pollution 158, 490-501.

Zheng, X.H., Mei, B.L, Wang, Y.H., Xie, B.H, Wang Y.S, Dong, H.B., Xu, H, Chen, G.X, Cai, Z.C., Yue, J., Gu, J.X., Su, F., Zou, J.W., Zhu, J.G., 2008. Quantification of $\mathrm{N}_{2} \mathrm{O}$ fluxes from soil-plant systems may be biased by the applied gas chromatograph methodology. Plant and Soil 311, 211-234. 